(C) 2020, The Authors. Published by Elsevier Inc. and Fass Inc. on behalf of the American Dairy Science Association ${ }^{\circledR}$. This is an open access article under the CC BY-NC-ND license (http://creativecommons.org/licenses/by-nc-nd/4.0/).

\title{
Effect of fortification with calcium from eggshells on bioavailability, quality, and rheological characteristics of traditional Polish bread spread
}

\author{
Joanna Kobus-Cisowska, ${ }^{1}$ Daria Szymanowska-Powałowska, ${ }^{2}$ Krystyna Szymandera-Buszka, ${ }^{1}$ \\ Ryszard Rezler, ${ }^{3}$ Maciej Jarzębski, ${ }^{3}$ Oskar Szczepaniak, ${ }^{1 *}$ Grzegorz Marciniak, ${ }^{4}$ Anna Jędrusek-Golińska, ${ }^{1}$ \\ and Małgorzata Kobus-Moryson ${ }^{1}$ \\ ${ }^{1}$ Department of Gastronomy Sciences and Functional Foods, Poznan University of Life Sciences, 60-637 Poznan, Poland \\ ${ }^{2}$ Department of Biotechnology and Food Microbiology, Poznan University of Life Sciences, 60-637 Poznań, Poland \\ ${ }^{3}$ Department of Physics and Biophysics, Poznan University of Life Sciences, 60-637 Poznań, Poland \\ ${ }^{4}$ Department of Macroeconomics and Agricultural Economics, Poznan University of Economics and Business, 61-875 Poznań, Poland
}

\section{ABSTRACT}

Hen eggshells are a rich and natural source of calcium and can serve as a biofunctional food ingredient. Enriching the traditional Polish bread spread (ser smażony) with micronized eggshell is an attractive proposition for consumers who require easily available calcium. The present study aimed to evaluate the use of micronized eggshells as a source of bioavailable calcium in bread spread. The study evaluated the effect of selected biocomponents on calcium bioavailability by using an in vitro digestion model. The enrichment of bread spread with eggshell, lysine, vitamin $\mathrm{D}_{3}$, and vitamin $\mathrm{K}$ enhanced all examined physicochemical variables except water activity. Enrichment with eggshells increased calcium levels $>2.5$-fold compared with the control sample. As an ingredient of bread spread, lysine is an important rheological factor. The bioavailability of calcium was higher in samples with lysine and vitamin $\mathrm{K}$ compared with samples that contained eggshell alone.

Key words: curd, eggshell, vitamins, bioavailability, texture

\section{INTRODUCTION}

Hen eggshells are a natural source of calcium in the form of calcium carbonate, which constitutes 92 to $96 \%$ of the raw material (Quina et al., 2017). Eggshell contains approximately 39\% $\mathrm{Ca}$ in terms of the elemental form. The remainder comprises magnesium and phosphorus compounds and organic compounds such as glycoproteins and proteoglycans (Al Mijan et al., 2014). Compared with other natural sources of calcium carbonate, eggshells are characterized by a higher

Received December 9, 2019.

Accepted March 28, 2020.

*Corresponding author: oskar.szczepaniak@up.poznan.pl content of strontium and selenium and a lower content of fluorine or harmful metals such as lead, cadmium, chromium, and aluminum (Brun et al., 2013; Al Mijan et al., 2014; Quina et al., 2017). Because of the attractive properties of eggshells, food products enriched with this by-product may an interesting alternative. Food products enriched with eggshells may be an attractive way to fortify the diets of people suffering from osteoporosis, or as an element to prevent the disorder, and the diets of children in the intensive growth stage. The key technological factor that may affect the use of eggshells as a food additive is the sensory effect resulting from the disturbance of rheological structure of the emulsion and the effects on physicochemical properties such as acidity, which determines the shelf life of the product during storage.

One option for consumers of dairy products is bread spread enriched with a biofunctional ingredient in the form of micronized hen eggshells. Fried cheese (Polish: ser smażony) is a traditional bread spread obtained from ripened acid curd cheese that is then fried with butter at approximately $80^{\circ} \mathrm{C}$. During ripening, the protein is subjected to natural maturation, which converts the structure of the curd into a characteristic vitreous mass. The characteristic smell of bread spread is formed at this stage, which is the effect of volatile compounds released in the form of aldehydes (e.g., acetaldehyde, 2-propenal), ketones (e.g., 2-nonanone, 2-pentanone, 2-heptanone), alcohols, acids (caproic, caprylic, lauric, myristic acids), lactones, and octadecanoic acid methyl ester (Majcher et al., 2014). The curd mass is then mixed with butter, salt, and sometimes caraway, and fried (Chudy and Makowska, 2014). Bread spread based on cottage cheese (another Polish curd-based product) is not a rich source of calcium compared with normal cheeses. The calcium content in the bread spread does not exceed $100 \mathrm{mg} / 100 \mathrm{~g}$, whereas normal cheeses contain $900 \mathrm{mg}$ of calcium/100 g. 
Supplementation of bread spread-type food product with hen eggshell is not technologically easy, with problems resulting from the texture of the shell itself among other things. One solution can be the use of raw material that has previously undergone a supercritical micronization process, a method being used increasingly in the food industry (Li et al., 2019). Obtaining powders with particles $<100 \mu \mathrm{m}$ is an important part of the process. The process requires the use of a high-pressure installation and appropriate equipment, which is costly at the investment stage. However, it is competitive in relation to other techniques at the operating stage.

The aim of this study was to demonstrate that eggshell could be used as a source of calcium in bread spread and to show that including eggshell in bread spread would have a positive effect on physicochemical, rheological, and sensory indicators, including during the refrigerated storage. Selected components added to bread spread with calcium from the shell would have an effect on the bioavailability of calcium in the in vitro digestion model.

\section{MATERIALS AND METHODS}

\section{Materials}

Bread Spread Preparation. Bread spread was prepared from lean curd $(62.0 \mathrm{~g}$ of curd/100 $\mathrm{g}$ of final bread spread), butter $(18.7 \mathrm{~g} / 100 \mathrm{~g})$, kitchen salt $(0.2$ $\mathrm{g} / 100 \mathrm{~g})$, and water $(19.1 \mathrm{~g} / 100 \mathrm{~g})$ that were added during heating $\left(85^{\circ} \mathrm{C}\right)$. The fermentation for bread spread production was prepared using Streptococcus spp. bacteria $\left(10 \mathrm{~h}\right.$ at $\left.25^{\circ} \mathrm{C}\right)$. Acidification was carried out until the acidity of the product was $31.2^{\circ} \mathrm{SH}$ (degrees Soxhlet-Henkel). The curd obtained was cut into smaller pieces. The last stage, dripping, was carried out using a press until the water content of the curd was $64 \%$. A key element of bread spread production is frying of the curd with the addition of butter ( $83 \%$ fat). Frying was carried out in a melting pot in which the temperature of the curd mass was maintained at $80 \pm$ $1^{\circ} \mathrm{C}$. Then, the cooled but not solidified bread spread was enriched with functional additives according to the following scheme: control sample without any additives (SK); spread with $265 \mathrm{mg}$ of eggshell (SK1); spread with $265 \mathrm{mg}$ of eggshell and $250 \mathrm{mg}$ of lysine per $100 \mathrm{~g}$ of curd (SS); spread with $265 \mathrm{mg}$ of eggshell, $250 \mathrm{mg}$ of lysine per $100 \mathrm{~g}$ of curd, and $15.0 \mu \mathrm{g}$ of vitamin $\mathrm{K}$ per $100 \mathrm{~g}$ of curd (SSK); spread with $265 \mathrm{mg}$ of eggshell, $1.0 \mu \mathrm{g}$ of vitamin $\mathrm{D}$, and $15.0 \mu \mathrm{g}$ of vitamin $\mathrm{K}$ per $100 \mathrm{~g}$ of curd (SDK); spread with $265 \mathrm{mg}$ of eggshell, $250 \mathrm{mg}$ of lysine, $1.0 \mu \mathrm{g}$ of vitamin $\mathrm{D}$, and $15.0 \mu \mathrm{g}$ of vitamin $\mathrm{K}$ per $100 \mathrm{~g}$ of curd (SSDK); spread with $265 \mathrm{mg}$ of eggshell, $250 \mathrm{mg}$ of lysine, and $1.0 \mu \mathrm{g}$ of vitamin D per $100 \mathrm{~g}$ of curd (SSD).

The melted curd mass was poured into 200-mL cups, closed, and stored until the analyses were carried out. The average nutritional value per $100 \mathrm{~g}$ of the tested products was estimated as follows: energy value 229 kcal; fat $16 \mathrm{~g}$, including $11 \mathrm{~g}$ of SFA; carbohydrates $1 \mathrm{~g}$, including $0 \mathrm{~g}$ of sugars; protein $19 \mathrm{~g}$, and salt 1.5 g (for more details see Bilska et al., 2019; GramzaMichałowska et al., 2016).

Bread Spread Components. The eggshell used was in powder form, creamy in color, with a slightly limestone smell and taste. The raw material was obtained from Eggnovo SI (Navarra, Spain). The composition of the shell preparation was as follows: $98 \%$ calcium carbonate, including $38 \%$ calcium, $2 \%$ soluble protein, and $250 \mathrm{ppm}$ strontium; $\mathrm{pH} 8.34$ in water solution, moisture 2.54, particle size $85 \%<50 \mu \mathrm{m}$. L-Lysine in the form of creamy-colored granules, devoid of taste and smell, was derived from NOW Foods (Bloomingdale, IL). Vitamin $\mathrm{K}_{2}$ (menaquinone-7, 0.1\%) in the form of white powder, devoid of taste and smell, was obtained from ForMeds Sp. z o. o. (Poznań, Poland). According to the information obtained from the manufacturer, the vitamin was produced from geraniol and farnesol, with the addition of inulin from chicory root. Vitamin $\mathrm{D}_{3}(1 \alpha, 25$-dihydroxycholecalciferol, 100PS-1) in the form of white powder, devoid of taste and smell, was purchased from ForMeds Sp. z o. o.

Dietary Supplements. The following supplements were used in this study: a mineral supplement in the form of hard tablets containing calcium, magnesium, and zinc (S1), a supplement in the form of effervescent tablets containing only calcium (S2), and a complex supplement in the form of hard tablets containing, in addition to calcium, 21 compounds such as vitamins and macro- and microelements (S3).

\section{Calcium Content}

Calcium content was determined by flame absorption atomic spectrometry according to the standardized method (PN-EN 13805:2014-11; Polish Standardizing Committee, 2014). Samples of extracts were pressuredigested in quartz crucibles in a muffle furnace at $500^{\circ} \mathrm{C}$. The white ash obtained, free of carbon, was dissolved while still hot in $1 \mathrm{NHNO}_{3}$. The filtered solutions were transferred quantitatively to $50-\mathrm{mL}$ volumetric flasks, and the volume was made up with nitric acid. The results were expressed as milligrams per $100 \mathrm{~g}$ of sample. 


\section{Acidity and Water Activity}

Acidity was determined using the titration method, and the results were presented in degrees Soxhlet-Henkel ( $\left.{ }^{\circ} \mathrm{SH}\right)$ according to De Marchi et al. (2009); the pH was measured with a $\mathrm{pH}$ meter (FiveEasy F20, Mettler Toledo, Columbus, $\mathrm{OH})$. Water activity $\left(\mathbf{a}_{\mathrm{w}}\right)$ was determined using a Thermoconstanter Novasina RTD 33 TH-1 avumeter (Novasina AG, Lacehn, Switzerland). The analysis was carried out in accordance with the requirements of the international standard regulating the determination of water activity in food products (ISO, 2017).

\section{Rheological Properties}

For these measurements, a dynamic rheological analyzer DMWT (CobraBiD, Poznań, Poland) was used. In rheometers operating on the principle of free vibration (the technique of dynamic thermal analysis), the viscoelastic properties of the examined systems are calculated by analyzing the parameters characterizing the curve of the free pendulum and damped vibrations with and without the sample (vibration frequency and damping decrement; Rezler and Poliszko, 2010). A cone-plate measuring system was used (cone diameter $30 \mathrm{~mm}$, angle $6^{\circ}$ ). The cone had a finely serrated surface. The complex modulus of elasticity was calculated based on elastic (or storage) modulus $\left(\mathbf{G}^{\prime}\right)$ and loss tangent $(\tan \delta)$. The elasticity modulus is associated with the part of potential deformation energy that is maintained during periodical deformations; $\tan \delta$ is a measure of internal friction. It describes the relative quantity of energy dissipated in the material during one deformation cycle. The frequency of the system's own vibrations amounted to $1.2 \mathrm{~Hz}$. Measurements were made at approximately $24^{\circ} \mathrm{C}$, and the temperature of the chamber and measurement plate was measured at an accuracy of $\pm 0.2^{\circ} \mathrm{C}$. The linear viscoelastic region of each sample was considered.

\section{Microscopy}

Typically, a few grams of the modified bread spread was taken from the bottom of the sample and put on a microscopic glass; no further preparation of the samples was needed before imaging. A polarization microscope Zeiss Axio Scope.A1 (Carl Zeiss, Jena Germany) and stereoscopic microscope Delta Optical SZ-630T (Delta Optical, Nowe Osiny, Poland) were used to evaluate the effect of additives on the morphology and structure of the bread spread.

\section{Sensory Analysis}

Investigations were conducted in an appropriately designed and equipped laboratory for sensory analysis. A 12-member trained panel conducted the sensory profiling. Members were students and academic staff of Poznań University of Life Sciences (Poznań, Poland). A total of 14 color and taste descriptors were used in the sensory profiling. The intensity of each score was determined using a $10-\mathrm{cm}$ linear scale with appropriate margin descriptions. For attributes of color and taste, uniform margin denotations were applied from "undetectable" to "very intense." Quality descriptors were selected and defined to assess the sensory profile of bread spreads: color (gray, yellow, white, gloss, uniform), taste (cheese, salty, bitter, fat, powder, metal), and structure (wateriness, granulation, lubrication). Individual bread spread samples, weighing approximately $30 \mathrm{~g}$, were placed in prepared, coded plastic containers $(150 \mathrm{~mL})$ and covered with lids. Unsweetened black tea $\left(45^{\circ} \mathrm{C}\right)$ was used as a taste neutralizer between the testing of the samples.

All of the analyses described above involved bread spread stored under refrigerated conditions $\left(4^{\circ} \mathrm{C}\right)$ at the following time intervals: immediately after production, $15 \mathrm{~d}$ after production, $30 \mathrm{~d}$ after production, and $45 \mathrm{~d}$ after production.

\section{In Vitro Digestion Model}

The experimental setup involved a 1-L fermentor (Sartorius, Göttingen, Germany). A set temperature of $37^{\circ} \mathrm{C}$ was maintained. Two experimental trials were conducted in this study. The first was the control run, which comprised bread spread dissolved in PBS ( $\mathrm{pH}$ 7.4; Sigma, St. Louis, MO). In the initial step, a mixture of bread spread was prepared in either PBS buffer or selected nutrient matrix. This prepared sample was subjected to the first step of in vitro digestion, which was designed to simulate the conditions in the stomach. A modeling mixture of gastric juice was prepared by adding $300 \mathrm{U} / \mathrm{mL}$ pepsin and lowering the $\mathrm{pH}$ to 4.0 (1 $M \mathrm{HCl})$. This step lasted $4 \mathrm{~h}$ at a temperature at $37^{\circ} \mathrm{C}$. Peristaltic movements were simulated by stirring with a magnetic stirrer. In the next step, digestion in the small intestine was simulated by changing the $\mathrm{pH}$ to 6.0 using $1 \mathrm{M} \mathrm{NaHCO}_{3}$ and adding $10 \mathrm{~mL}$ of pancreaticintestinal extract. The next step was to increase the $\mathrm{pH}$ to 7.4 by adding $1 \mathrm{M} \mathrm{NaHCO}_{3}$ and introducing a standardized inoculum of intestinal microflora $\left(10^{6} \mathrm{cfu} /\right.$ $\mathrm{mL}$ of food content) isolated from human stool. The process was carried out for $2 \mathrm{~h}$ at $37^{\circ} \mathrm{C}$. To simulate the 
passage of the product through the large intestine, the $\mathrm{pH}$ was increased to 8.0 with $2 \mathrm{M} \mathrm{NaHCO}_{3}$, and further digestion was carried out under anaerobic conditions for $18 \mathrm{~h}$.

\section{Simulation of Calcium Bioabsorption}

Ten grams of bread spread sample was used to determine bioabsorption or, in the case of supplements $\mathrm{S} 1, \mathrm{~S} 2$, and $\mathrm{S} 3$, the sample was weighed to $25 \%$ of the single dose and supplemented with distilled water up to $50 \mathrm{~g}$. Then, the in vitro digestion process was carried out. The homogenate obtained was quantitatively transferred to cellulose dialysis membranes and shaken in a water bath at $37^{\circ} \mathrm{C}$ for $2 \mathrm{~h}$. After digestion, the dialysis tubes were emptied and $50 \mathrm{~g}$ of homogenate was weighed into quartz crucibles and subjected to dry mineralization in a muffle furnace at $450^{\circ} \mathrm{C}$. After mineralization, the samples were quantitatively transferred to $50-\mathrm{mL}$ volumetric flasks. Calcium content was determined by atomic absorption spectrometry. The determination of calcium content in dialysates from dialysis solutions was performed using the same method. A blind reagent test was performed for calcium, and the results obtained were subtracted from the results obtained in particular systems. Each sample was analyzed in 6 repetitions, and the relative bioavailability results for the system were expressed as mean \pm SD. Potential relative bioavailability in \% (B\%) was expressed as the ratio of the amount of mineral component diffused through the membrane that was in equilibrium in the whole volume of the tested system to the total amount of this element in the tested system; that is, the sum of the amount present in the homogenate inside the dialysis tube $(\mathbf{T})$ and in the dialysate $(\mathbf{D})$, multiplied by $100: \mathrm{B} \%=[\mathrm{D} /(\mathrm{T}+\mathrm{D})] \times 100$.

\section{Statistical Analysis}

The rheological and textural results were analyzed using SPSS software (ver. 13.0; SPSS Inc./IBM Corp., Armonk, NY). The significance (least significant difference test) of the results at $P<0.05$ was tested by one-way ANOVA. To evaluate the differences and similarities of the sensory profiles of the examined bread spread samples on the basis of color, taste, and structural characteristics, principal components analysis (PCA) was applied. Results were subjected to one-way ANOVA (Statistica Software 13.0; TIBCO Software, Palo Alto, CA) using Tukey's test. Hypotheses were tested at $\alpha=0.01$.

\section{RESULTS}

\section{Physicochemical Analyses}

Physicochemical analyses of the bread spread type products were carried out in the first stage of the study. Seven variants were examined, the composition of which is given in the Materials and Methods section.

Key indices in dairy product processing such as $\mathrm{a}_{\mathrm{w}}$, acidity, and $\mathrm{pH}$ were determined. The results of variance analysis related to the effect of technological additives such as hen eggshells, lysine, and vitamins D and $\mathrm{K}$ on bread spread properties are presented in Table 1. Enrichment of bread spread in eggshell blends allowed us to increase the calcium content by $114-122 \mathrm{mg} / 100$ g compared with the control $(78 \mathrm{mg} / 100 \mathrm{~g})$. Differences in $\mathrm{Ca}$ content between enriched samples were not significant, whereas the Ca contents of all samples with eggshell were significantly higher than that of the control $(P<0.05)$. Bread spread enrichment affected all examined variables except $\mathrm{a}_{\mathrm{w}}$, including an increase in the active acidity of products expressed as $\mathrm{pH}$ and a decrease in titration acidity from $76.65^{\circ} \mathrm{SH}$ in the control sample to $72.34^{\circ} \mathrm{SH}$ in the SSK sample and $72.76^{\circ} \mathrm{SH}$ in the SS sample $(P<0.05)$. Storage of bread spread enriched with calcium from eggshells increased active acidity and thus decreased titration acidity. All observed differences in the acidity of the examined samples and the changes observed during storage were significant based on a 2-factor ANOVA. Samples enriched with eggshell, regardless of the composition of individual additives, had $>2.5$-fold more calcium than the control sample; enriched samples averaged $196 \mathrm{mg}$ of calcium/100 g of product. The enrichment of bread spread with calcium and other biocomponents did not significantly affect $\mathrm{a}_{\mathrm{w}}$, which did not change during 45 d of storage.

\section{Rheological Tests}

We analyzed the effect of the addition of eggshell, lysine, and biocomponents (vitamins $\mathrm{K}$ and $\mathrm{D}$ ) to bread spread on rheological properties $\left(\mathrm{G}^{\prime}\right.$ and $\left.\tan \delta\right)$. The control specimen for these evaluations was the bread spread sample without any additives (SK).

Figure 1 shows the actual component of the combined $G^{\prime}$ of the analyzed bread spread samples. The sample with added calcium (SK1) demonstrated similar $\mathrm{G}^{\prime}$ as the control sample (SK). The addition of lysine to the basic composition of the bread spread samples contributed to a significant increase in $\mathrm{G}^{\prime}(P<0.05)$ compared with the control sample (SK). The presence 


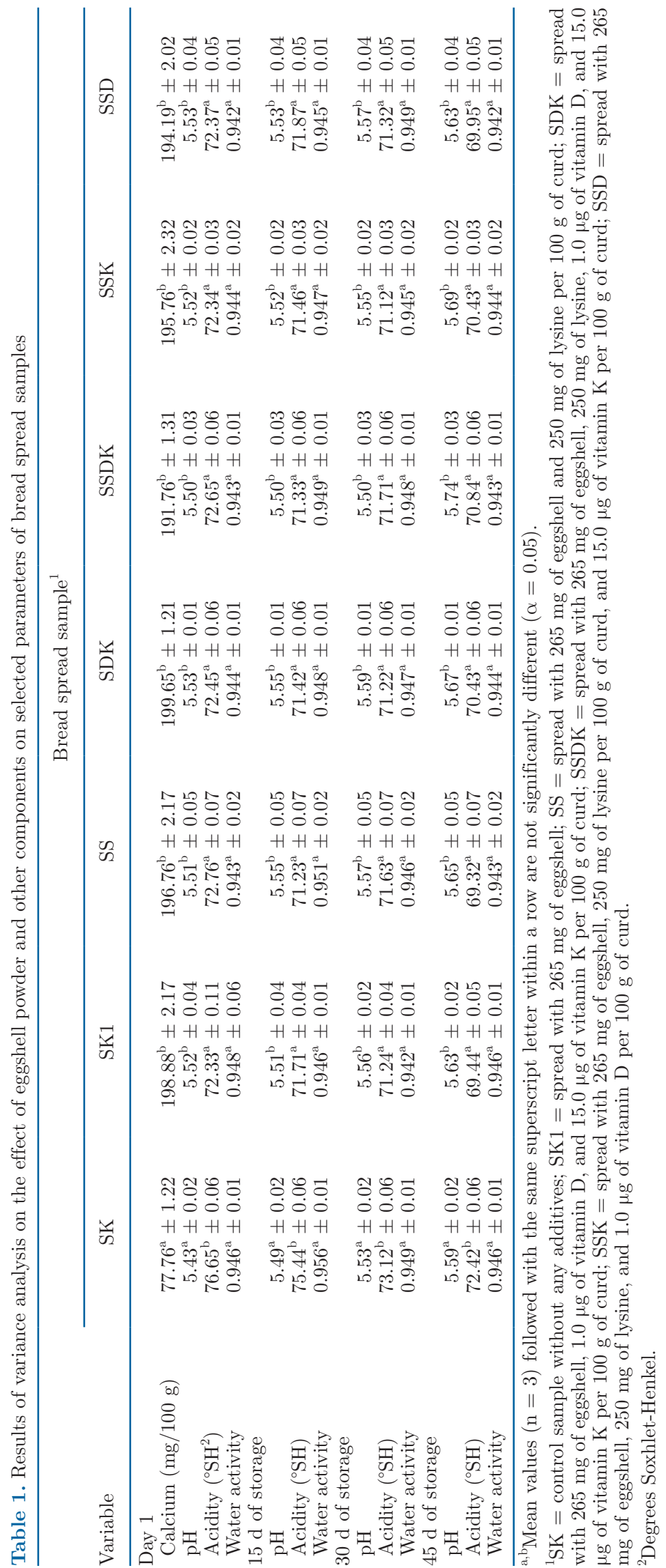



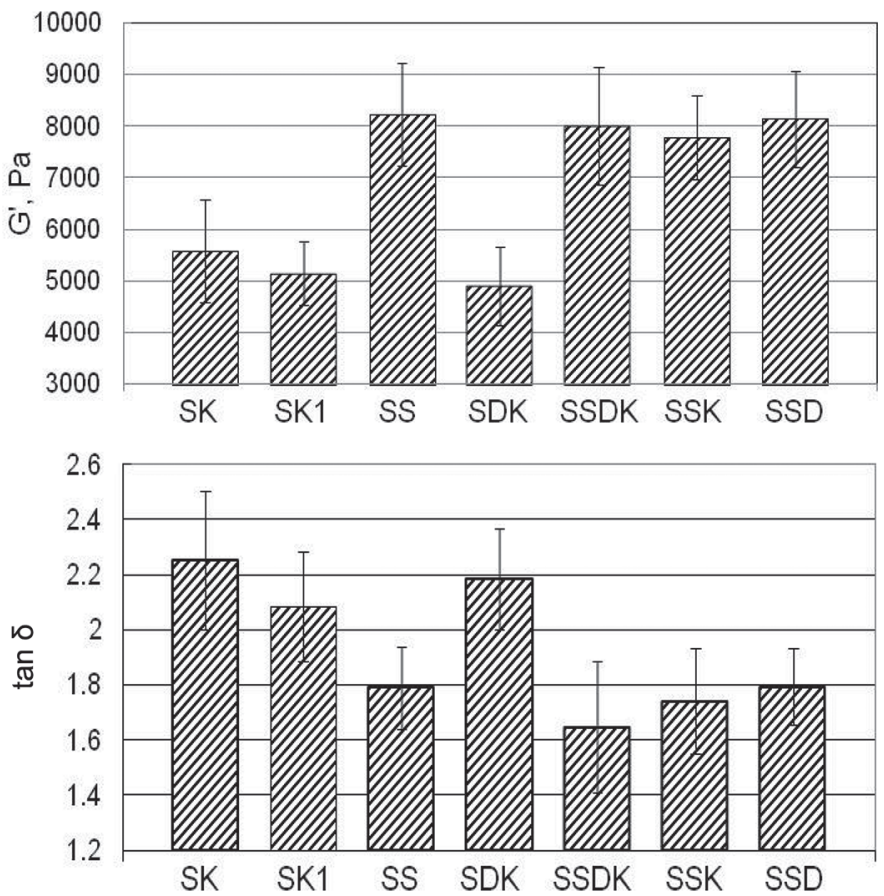

Figure 1. Storage modulus ( $\mathrm{G}^{\prime} ;$ top) and tan $\delta$ (bottom) of bread spread samples $(\mathrm{n}=3)$ with an addition of eggshell, lysine, and vitamins K and D. Error bars represent SD. SK = control sample without additives; SK1 = spread with $265 \mathrm{mg}$ of eggshell; SS = spread with 265 $\mathrm{mg}$ of eggshell and $250 \mathrm{mg}$ of lysine per $100 \mathrm{~g}$ of curd; SDK = spread with $265 \mathrm{mg}$ of eggshell and $1.0 \mu \mathrm{g}$ of vitamin D; SSDK = spread with $265 \mathrm{mg}$ of eggshell, $250 \mathrm{mg}$ of lysine, $1.0 \mu \mathrm{g}$ of vitamin $\mathrm{D}$, and $15.0 \mu \mathrm{g}$ vitamin $\mathrm{K}$ per $100 \mathrm{~g}$ of curd; SSK = spread with $265 \mathrm{mg}$ of eggshell, $250 \mathrm{mg}$ of lysine, and $15.0 \mu \mathrm{g}$ of vitamin $\mathrm{K}$ per $100 \mathrm{~g}$ of curd; SSD = spread with $265 \mathrm{mg}$ of eggshell, $250 \mathrm{mg}$ of lysine, and $1.0 \mu \mathrm{g}$ of vitamin D per $100 \mathrm{~g}$ of curd.

of lysine and vitamins $\mathrm{K}$ and D (samples SSDK, SSK, and SSD) did not significantly affect $G^{\prime} ; G^{\prime}$ values were approximately 8,000 $\mathrm{Pa}$. In contrast, the sample containing vitamins $\mathrm{K}$ and $\mathrm{D}$ (SDK) showed lower values of $\mathrm{G}^{\prime}$ than the control sample $(\sim 4,900$ and $\sim 5,500 \mathrm{~Pa}$, respectively; $P<0.05)$. However, their $\tan \delta$ values (Figure $1 \mathrm{~b}$ ) were not different and were $>2$ (samples SK and SDK). Bread spreads containing both lysine and lysine plus biocomponents (samples SS, SSDK, SSK, and SSD) had similar $\tan \delta$ values $(P<0.05)$ $<2$. Significantly higher $(P<0.05)$ values of $\mathrm{G}^{\prime}$ with lower values of $\tan \delta$ of these samples show their lower plasticity compared with other samples.

\section{Microscopy}

Figures $2 \mathrm{a}$ and $2 \mathrm{~b}$ show photographs of the surface of selected bread spreads (SS, SDK, SSK, SSD, and SSDK). These samples were selected for detailed study due to their high calcium contents. Analysis of surface morphology and topography confirmed the lack of visi- ble agglomerates of particles originating from powdered modifiers. No clear heterogeneities were visible on the surface (Figure 2a), confirming the thorough mixing of additives in the technological process. Images from the stereographic microscope (Figure 2b, panels B, C, and D) show the structure of the bread spread in crosssection. From the studied samples we chose 2 (SSD and SSK) to present, for which no visible aggregates occurred during imaging in different sections (see Figure 2a, panels D and E, and Figure 2b, panels C and D). The microscopic imaging confirmed high homogeneity of the prepared bread spreads.

\section{Sensory Profile Evaluation}

The following descriptors were defined and noted in the bread spreads evaluated by the sensory panel: color (gray, yellow, white, gloss, uniformity), taste (cheeselike, salty, bitter, fat), and structure (wateriness, lubrication). Based on the PCA, one main factor related to bitter taste was identified (Table 2), contributing $98 \%$ of the variability of sensory quality of the bread spread samples evaluated.

Regardless of the additives in the bread spread, very similar profiles of color, taste, and texture were found in all samples (Table 3 and Figure 3). No significant differences were found in intensities of the attributes evaluated. High uniformity of color was observed on the surface and in cross-section. Similar tendencies were found in the taste profile evaluation. All samples had similar intensities of cheese-like, salt, fat, and powder taste. There was no sensation of powder or metallic taste in samples with the addition of calcium. Similarly, no bread spreads had graininess identified in the evaluation of the structure. We found significant deviations between samples only for bitter taste $(P<0.01)$. The sample of bread spread without calcium (SK) was characterized by a bitter taste intensity of 1.5 , whereas the sample with calcium (SK1) did not show any noticeable presence of this descriptor. However, the intensity of bitter taste increased to 2.5 in samples with lysine (SS). Bitter taste scored 1.4 in samples with lysine and vitamin K (SSK) but was absent in SSD, SSDK, and SDK samples. It is worth noting that all prepared samples of bread spread exhibited microbiological stability, both immediately after the production process and during the storage (data not shown).

\section{Analysis of Biofunctionality}

We evaluated biological absorption of calcium after in vitro digestion using bread spread without functional additives (control sample) and bread spread with egg- 
$\mathbf{a}$
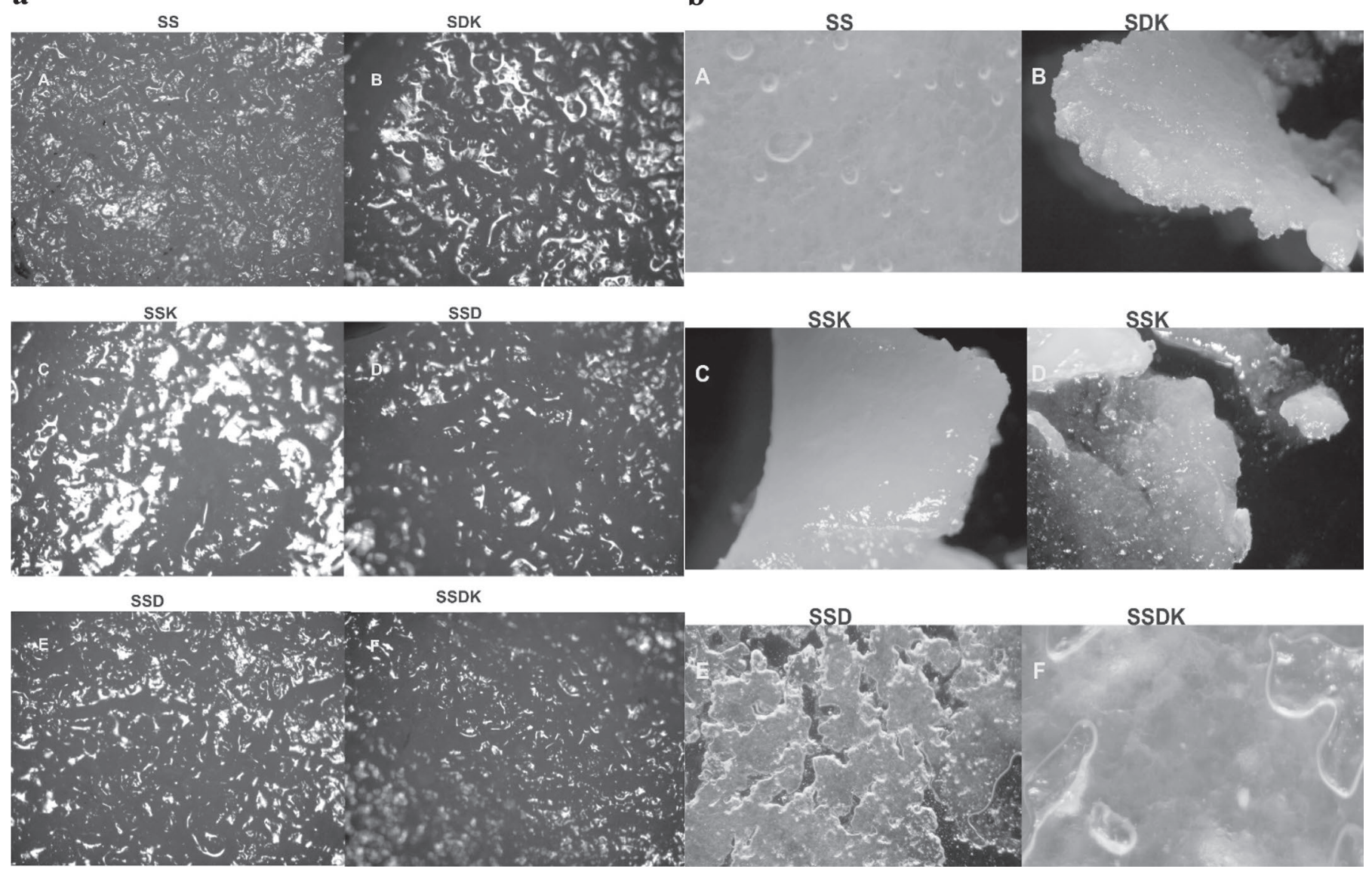

Figure 2. Surface of selected bread spread samples by (a) polarization microscopy, and (b) stereoscopic microscopy. SS $=$ spread with 265 $\mathrm{mg}$ of eggshell and $250 \mathrm{mg}$ of lysine per $100 \mathrm{~g}$ of curd; SDK = spread with $265 \mathrm{mg}$ of eggshell and $1.0 \mu \mathrm{g}$ of vitamin D; SSK = spread with 265 $\mathrm{mg}$ of eggshell, $250 \mathrm{mg}$ of lysine, and $15.0 \mu \mathrm{g}$ of vitamin K per $100 \mathrm{~g}$ of curd; SSD = spread with $265 \mathrm{mg}$ of eggshell, $250 \mathrm{mg}$ of lysine, and 1.0 $\mu \mathrm{g}$ of vitamin D per $100 \mathrm{~g}$ of curd; SSDK = spread with $265 \mathrm{mg}$ of eggshell, $250 \mathrm{mg}$ of lysine, $1.0 \mu \mathrm{g}$ of vitamin $\mathrm{D}$, and $15.0 \mu \mathrm{g}$ vitamin $\mathrm{K}$ per $100 \mathrm{~g}$ of curd.

Table 2. Factor-variable correlations (factor loadings) of sensory analysis based on correlations for bread spread samples

\begin{tabular}{|c|c|c|c|c|c|}
\hline \multirow{2}{*}{$\begin{array}{l}\text { Bread spread } \\
\text { sample }^{1}\end{array}$} & \multicolumn{5}{|c|}{ Factor-variable correlations (factor loadings) } \\
\hline & Factor I & Factor II & Factor III & Factor IV & Factor V \\
\hline SK & -0.9947 & 0.0665 & 0.0679 & 0.0030 & 0.040 \\
\hline SK1 & -0.9962 & -0.0698 & 0.0136 & -0.0311 & 0.0386 \\
\hline SS & -0.9827 & 0.0177 & 0.0100 & -0.0478 & -0.0253 \\
\hline SDK & -0.9944 & -0.0872 & 0.0490 & 0.0091 & 0.0142 \\
\hline SSDK & -0.9957 & -0.0770 & 0.0453 & 0.0133 & -0.0053 \\
\hline SSK & -0.9902 & 0.0647 & -0.0963 & 0.0777 & 0.0054 \\
\hline SSD & -0.9961 & -0.0700 & 0.0167 & 0.0134 & -0.0460 \\
\hline
\end{tabular}

${ }^{1} \mathrm{SK}=$ control sample without any additives; SK1 = spread with $265 \mathrm{mg}$ of eggshell; SS = spread with $265 \mathrm{mg}$ of eggshell and $250 \mathrm{mg}$ of lysine per $100 \mathrm{~g}$ of curd; SDK = spread with $265 \mathrm{mg}$ of eggshell, $1.0 \mu \mathrm{g}$ of vitamin $\mathrm{D}$, and $15.0 \mu \mathrm{g}$ of vitamin K per $100 \mathrm{~g}$ of curd; SSDK = spread with $265 \mathrm{mg}$ of eggshell, $250 \mathrm{mg}$ of lysine, 1.0 $\mu \mathrm{g}$ of vitamin D, and $15.0 \mu \mathrm{g}$ of vitamin K per $100 \mathrm{~g}$ of curd; SSK = spread with $265 \mathrm{mg}$ of eggshell, $250 \mathrm{mg}$ of lysine per $100 \mathrm{~g}$ of curd, and $15.0 \mu \mathrm{g}$ of vitamin K per $100 \mathrm{~g}$ of curd; SSD = spread with $265 \mathrm{mg}$ of eggshell, $250 \mathrm{mg}$ of lysine, and $1.0 \mu \mathrm{g}$ of vitamin D per $100 \mathrm{~g}$ of curd. 
shells, vitamin $\mathrm{D}_{3}$, and lysine. We also analyzed calcium bioavailability of 3 commercial dietary supplements by in vitro digestion (Table 4). We found no significant differences in the level of calcium bioavailability depending on the presence of biofunctional additives in bread spread. For dietary supplements, however, the composition of the supplement and its pharmaceutical form were important. For bread spread samples, the relative bioavailability of Ca was $37.5 \%$ (SK) and $36.5 \%$ (SSDK; Table 4). For supplements, the highest bioavailability was demonstrated for supplement S1 (35.1\%), which contained calcium carbonate, gluconate, magnesium, and zinc. The lowest $(23.3 \%)$ was obtained for S2.

\section{DISCUSSION}

It is not easy to design and optimize the technological process for and produce a new range of biofunctional foods to meet the needs of consumers experiencing health problems such as food intolerance and nutrient deficiencies. Development of a new product requires an idea, technological knowledge, knowledge of dietary issues, and market demand. An important element of food product development (apart from the development of composition and process parameters) is the selection and analysis of key product indicators that allow quality to be assessed.

The $\mathrm{a}_{\mathrm{w}}$ in food products indicates the degree of the association of water molecules with food ingredients. Its value indicates the availability of water for microorganisms, and thus, their potential for development, which affects the quality of products and their durability. Among dairy products, skim milk powder has an $\mathrm{a}_{\mathrm{w}}$ of 0.254 and a shelf life of 6 mo, whereas curd has an $\mathrm{a}_{\mathrm{w}}$ of 0.955 and a shelf life of $48 \mathrm{~h}$ (Bedoya-Serna et al., 2018). According to the $\mathrm{a}_{\mathrm{w}}$ level, the following microorganisms may develop in milk and dairy products: $\mathrm{a}_{\mathrm{w}}>0.95$, Pseudomonas spp., Escherichia spp., Proteus spp., Shigella spp., Klebsiella spp., Clostridium perfringens, and some yeasts; $\mathrm{a}_{\mathrm{w}}$ from 0.91 to 0.95 , Salmonella spp., Clostridium botulinum spp., Serratia spp., Lactobacillus spp., Pediococcus spp., Bacillus spp., and some molds; and $\mathrm{a}_{\mathrm{w}}$ from 0.87 to 0.91 , Micrococcus spp., and yeasts such as Candida spp. (Camardo Leggieri et al., 2018).

The results of the present study indicate that $\mathrm{a}_{\mathrm{w}}$ in dairy products, including curds, can change depending on the technological processes and maturation time. Frying the curd might stabilize the microbiological quality of the product. The study has shown that bread spread, regardless of the fortification with calcium in the presence of other ingredients affecting its bioavailability, was characterized by $\mathrm{a}_{\mathrm{w}}$ that enabled its storage for several weeks, and the additives did not change the examined variables (Table 1). According to the literature, the chemical composition of processing milk (i.e., fat content, quantity, and composition of casein) plays the most important role in curd production (BedoyaSerna et al., 2018; Morandi et al., 2019).

The $\mathrm{pH}$ values of beverages enriched with $50 \mathrm{mg}$ of $\mathrm{Mg} / 100 \mathrm{~g}$ and 80 or $100 \mathrm{mg}$ of $\mathrm{Ca} / 100 \mathrm{~g}$ were significantly higher than those of samples without $\mathrm{Mg}$ and $\mathrm{Ca}$ added (Szpendowski et al., 2004), which is consistent

Table 3. Characteristics of sensory taste profiling of the tested bread spread samples

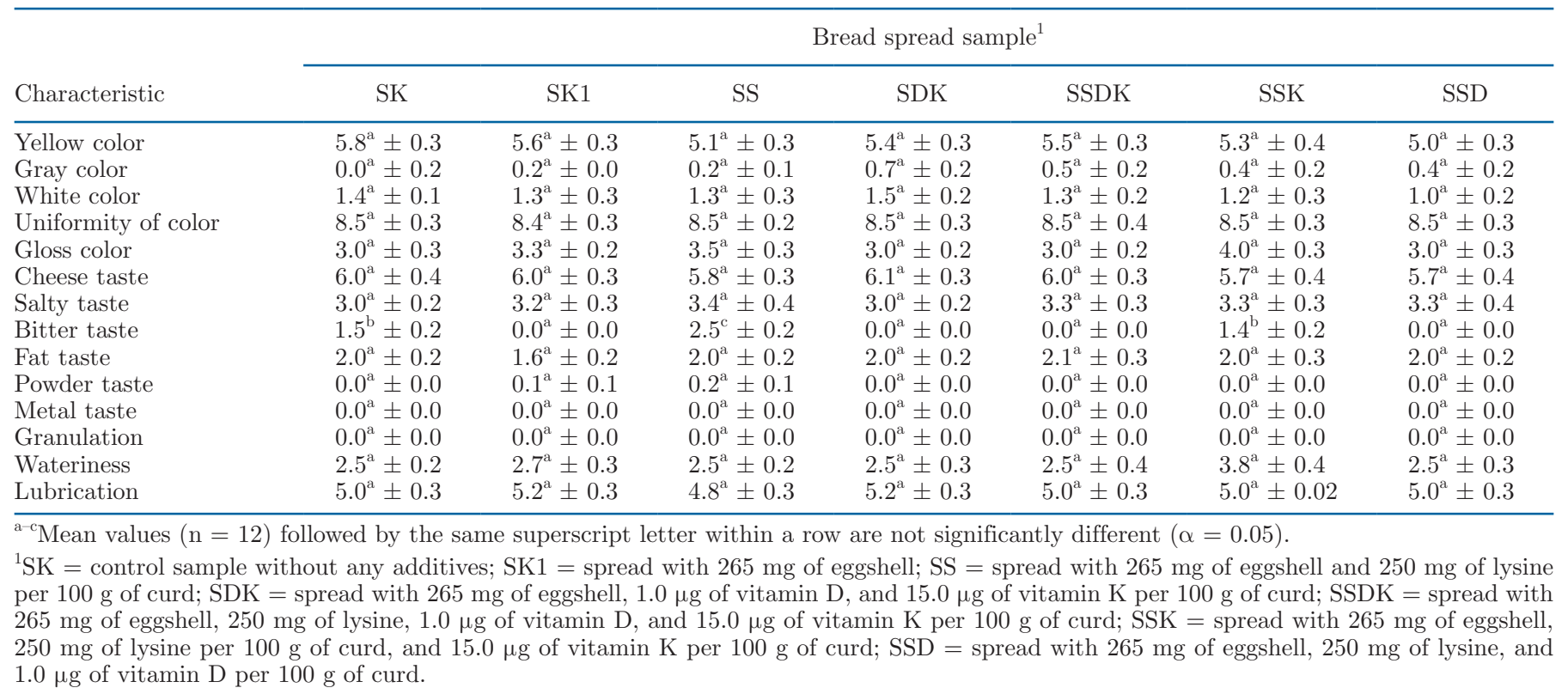


Table 4. Calcium bioavailability of bread spread samples and commercial dietary supplements after the in vitro digestion process of the tested samples $(\mathrm{n}=3)$

\begin{tabular}{lccccc}
\hline & \multicolumn{5}{c}{ Sample $^{2}$} \\
\cline { 2 - 5 } Variable $^{1}$ & SK & SSDK & S1 & S2 & S3 \\
\hline $\mathrm{n}(\mathrm{mg}) \pm \mathrm{SD}$ & $26.9^{\mathrm{c}} \pm 3.2$ & $25.1^{\mathrm{c}} \pm 2.2$ & $19.1^{\mathrm{b}} \pm 1.3$ & $13.7^{\mathrm{a}} \pm 1.1$ & $12.9^{\mathrm{a}} \pm 1.0$ \\
$\mathrm{~T}(\mathrm{mg}) \pm \mathrm{SD}$ & $44.8^{\mathrm{b}} \pm 1.1$ & $43.6^{\mathrm{b}} \pm 1.0$ & $35.2^{\mathrm{a}} \pm 2.3$ & $45.1^{\mathrm{b}} \pm 2.3$ & $42.1^{\mathrm{b}} \pm 2.1$ \\
$\mathrm{~B}(\%)$ & $37.5^{\mathrm{b}}$ & $36.5^{\mathrm{b}}$ & $35.1^{\mathrm{b}}$ & $23.3^{\mathrm{a}}$ & $23.4^{\mathrm{a}}$ \\
\hline
\end{tabular}

${ }^{\mathrm{a}-\mathrm{c}}$ Mean values followed by the same superscript letter within a row are not significantly different $(\alpha=0.05)$. ${ }^{1} \mathrm{D}=$ dialysate; $\mathrm{T}=$ dialysis tube; $\mathrm{B}=$ potential relative bioavailability.

${ }^{2} \mathrm{SK}=$ control sample without additives; $\mathrm{SSDK}=265 \mathrm{mg}$ of eggshell, $250 \mathrm{mg}$ of lysine, $1.0 \mu \mathrm{g}$ of vitamin D, and $15.0 \mu \mathrm{g}$ vitamin $\mathrm{K}$ per $100 \mathrm{~g}$ of curd; $\mathrm{S} 1$ = mineral supplement containing calcium, magnesium, and zinc; $\mathrm{S} 2=$ calcium supplement; $\mathrm{S} 3$ = calcium supplement plus vitamins and macro- and microelements.

with the results obtained in the current study. pH affects the compactness of the casein clot, which may affect texture and sensory evaluation. In the classical method of producing curd, the basic raw material in bread spread, up to $60 \%$ of the calcium is lost along with the separated whey. The addition of calcium to

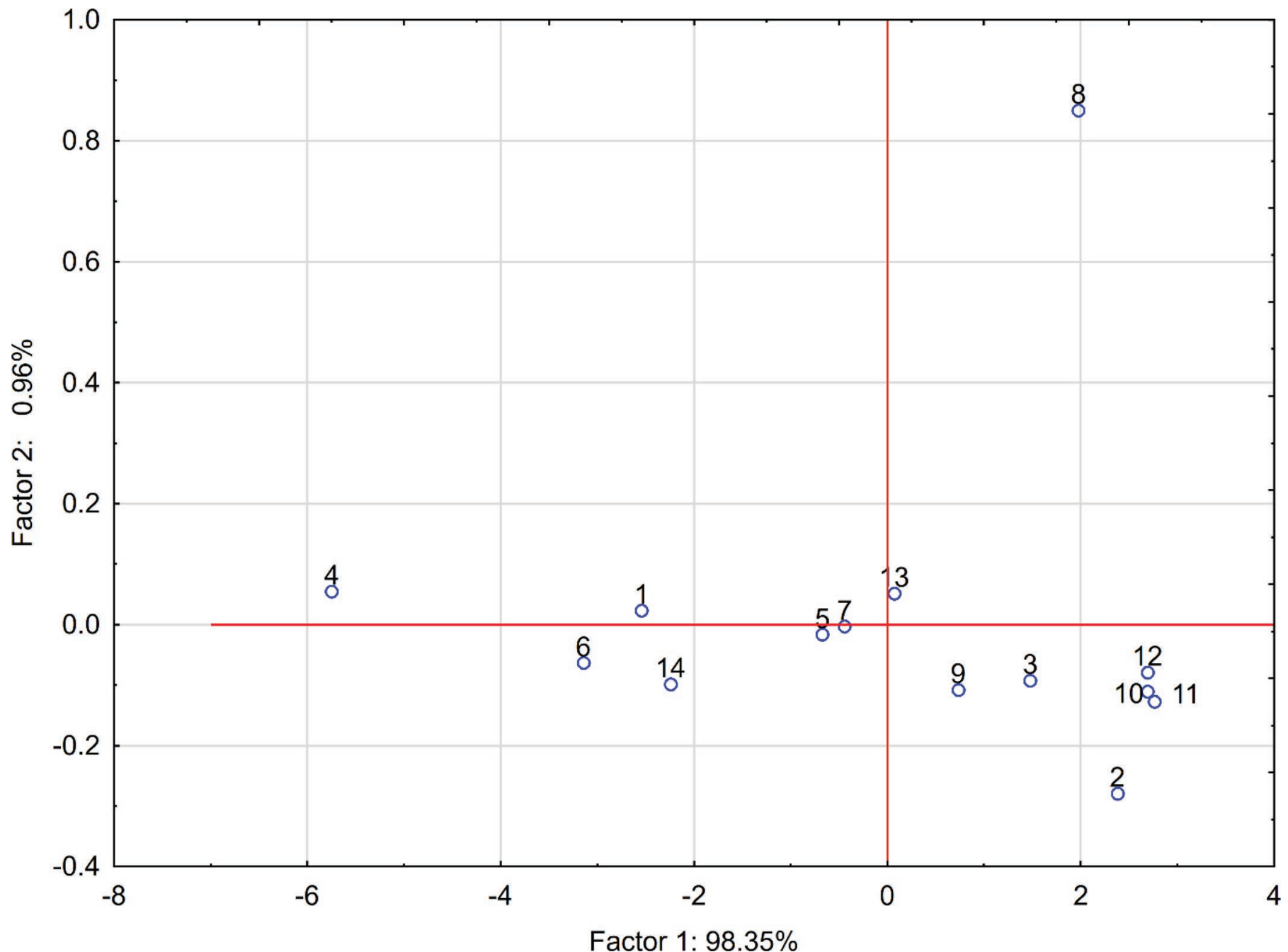

Figure 3. The projection of cases on the factor plane for sample coding: $1=$ yellow color; $2=$ gray color; $3=$ white color; $4=$ uniformity of color; $5=$ gloss color; $6=$ cheese-like taste; $7=$ salty taste; $8=$ bitter taste; $9=$ fat taste; $10=$ powder taste; $11=$ metal taste; $12=$ granulation; $13=$ wateriness; $14=$ lubrication material. 
curd during manufacturing helped to strengthen the casein clot formed by acid coagulation of these proteins, through the action of starter cultures and indirectly through the effect of acidity change (Table 2). Bread spread forms gel fat-protein emulsions; that is, gels made of protein matrix with drops of emulsions deposited in them (Bowland and Foegeding, 1999).

Addition of calcium-based preparations to the bread spread allowed us to create a product in which calcium content ranged between 191 and $199 \mathrm{mg} / 100 \mathrm{~g}$. Increased calcium content may affect the texture of the final product, which has been shown in, for example, fruit spreads. Based on the sensory evaluation, it was found that a spread with a higher content of calcium showed a higher value of hardness, but the general sensory evaluation was lower (Lentas and Witrowa-Rajchert, 2008). In the case of cottage cheese production, milk addition enhanced total calcium and phosphorus content (Szpendowski et al., 2005). In that study, the authors noted that increased addition of calcium during curd coagulation increased the content of phosphorus accumulating in the curd. Therefore, calcium can affect final curd structure and nutritional value when added during as well as after the coagulation process.

From a physical point of view, bread spreads are dispersive systems. Proteins form a spatial network in the continuous phase and the emulsified fat is the dispersed phase. The continuous phase determines elastic properties and the dispersed phase affects dissipative properties. Therefore, the rheological properties of bread spread reflect the spatial reaction of the protein matrix to dynamic interactions, and changes in their values result from conformational transformations occurring in the structure of segments and nodes of the spatial network, determined by the degree of interaction between its components: water, fat, and protein (da Silva et al., 2019b). The analysis of the $\mathrm{G}^{\prime}$ results (Figure 1a) for the tested bread spreads showed that the addition of lysine to the samples contributed to a significant increase in $\mathrm{G}^{\prime}$, from 5,500 to $\sim 8,000$ $\mathrm{Pa}$, compared with the control sample. The $\mathrm{G}^{\prime}$ value is affected by the organization of the spatial matrix, including the density of its segments and the organization within the network segments (Zanutto-Elgui et al., 2019). The share of emulsified soluble proteins is equally important in shaping $\mathrm{G}^{\prime}$ value of the spatial matrix. In part, the presence of lysine in the samples favors an increase in the density of protein matrix segments by forming ionic interactions and hydrogen bonds between the polypeptide chains of proteins (Albenzio et al., 2015; Gluvić and Ulrih, 2019). In contrast, complexes formed with endogenous calcium metallic ions increase the retention of water by the protein matrix, which increases the degree of fat emulsification. Hence, lysine added during bread spread production is an important structure-forming factor, with a significant role in shaping its rheological properties. Enrichment of bread spread with calcium from eggshells did not significantly improve the rheological properties (Figure 1a,b). Bread spread samples containing eggshell with vitamin $\mathrm{D}$ and vitamin $\mathrm{K}$ (SDK) showed an almost $10 \%$ decrease in $\mathrm{G}^{\prime}$ compared with that of the control sample (SK), probably because excess calcium ions can adversely affect the solubility of the protein, resulting in weaker fat emulsifying properties. During the production of bread spread (SDK), containing only calcium and additives (vitamins $\mathrm{K}$ and $\mathrm{D}$ ), without the addition of lysine, only part of the calcium is released from eggshell. When powdered ingredients are used for food product development, microscopy studies are recommended to evaluate possible agglomeration of particles in the samples (Jarzębski et al., 2017). The analysis of surface morphology and topography in the current study showed no agglomerates or aggregates of particles that would adversely affect the organoleptic or visual perception of the final product by the consumer (Figure 2). The remaining shell particles in curd systems act as a dissipative filler. Despite a slight decrease in $\mathrm{G}^{\prime}$, the system retained its plastic properties. No significant differences were observed in $\tan \delta$ values $(>2)$ between the SDK and SK bread spread samples analyzed; analysis of the remaining samples was carried out earlier (Results: Rheological Tests). The effect of excess of calcium ions also contributes in the other curd samples. However, its effects are masked by the structure-forming function of lysine. Earlier studies confirmed the possibility of bitter taste occurring with the addition of lysine (Schiffman and Dackls, 1975), a complex substance that is salty with some bitter ingredients. The addition of fat-soluble vitamins is likely to block the perception of these sensations (Ley, 2008). In a previous study, eggshell used in production of chocolate cakes was added in a larger amount than was used in the current study (3-9\% of the raw material content; Ray et al., 2017). We showed that $3 \%$ eggshell did not negatively affect color, taste, texture, or mouthfeel, which confirms the hypothesis of this study that micronized shell may be a useful ingredient to enrich bread spread with bioavailable calcium.

Most of the calcium contained in food is in the form of salts or complexes with other nutrients. These compounds must be dissociated because calcium is only absorbed in cationic form. Many factors interfere with the process of calcium absorption (da Silva et al., 2019a; Wu et al., 2019). The bioavailability of calcium is adversely affected if the protein content is too high; that is, when the calcium $(\mathrm{mg})$ :protein $(\mathrm{g})$ ratio is $<20$ (Ren et al., 2018; Lynch Cronin et al., 2019). The recommended calcium:protein ratio is $16 \mathrm{mg}$ of Ca to $1 \mathrm{~g}$ of protein. 
This ratio minimizes the degree of calcium excretion from the body. Excessive amounts of protein in the diet increase diuresis and thus the removal of calcium with urine. Bread spreads made from cottage cheese and ser smażony have a lower calcium than phosphorus content, which impairs assimilability of calcium from this group of dairy products.

\section{CONCLUSIONS}

Hen eggshell is an attractive biofunctional food additive because of its high concentration of easily digestible calcium. To evaluate the synergistic effects of calcium (from hen eggshells), bread spread was also enriched in lysine and vitamins $\mathrm{K}$ and D. Imaging studies showed no evidence of agglomerates or aggregates of the incorporated additives so they should not negatively affect sensory characteristics. The use of hen eggshell in bread spread affected none of the tested physicochemical, rheological, or sensory factors and did not affect storage stability. The proposed set of bioactive ingredients (i.e., eggshell-derived compounds, lysine, vitamins $\mathrm{K}$ and D) makes this breakfast product an interesting and appealing alternative to dietary calcium supplements. Moreover, we showed that a waste food product (eggshell), after technological processing, can be useful as a food supplement.

\section{ACKNOWLEDGMENTS}

This work was financed by the National Center of Research and Development (Warsaw, Poland), developed as project POIR.04.01.02-00-0059/17, and from statutory funds of the Department of Gastronomy Sciences and Functional Foods of Poznań University of Life Sciences (Poznań, Poland; grant number 506.751.03.00. The authors have stated no conflicts of interest.

\section{REFERENCES}

Al Mijan, M., K.-H. Choi, and H.-S. Kwak. 2014. Physicochemical, microbial, and sensory properties of nanopowdered eggshell-supplemented yogurt during storage. J. Dairy Sci. 97:3273-3280. https:/ /doi.org/10.3168/jds.2013-7367.

Albenzio, M., A. Santillo, R. Marino, A. Della Malva, M. Caroprese, and A. Sevi. 2015. Identification of peptides in functional Scamorza ovine milk cheese. J. Dairy Sci. 98:8428-8432. https://doi.org/ $10.3168 /$ jds.2015-9844.

Bedoya-Serna, C. M., G. C. Dacanal, A. M. Fernandes, and S. C. Pinho. 2018. Antifungal activity of nanoemulsions encapsulating oregano (Origanum vulgare) essential oil: In vitro study and application in Minas Padrão cheese. Braz. J. Microbiol. 49:929-935. https://doi.org/10.1016/j.bjm.2018.05.004.

Bilska, A., J. Kobus-Cisowska, D. Kmiecik, B. Danyluk, R. Kowalski, D. Szymanowska, A. Gramza-Michałowska, and O. Szczepaniak. 2019. Cholinesterase inhibitory activity, antioxidative potential and microbial stability of innovative liver pâté fortified with rose- mary extract (Rosmarinus officinalis). Electron. J. Biotechnol. 40:22-29. https://doi.org/10.1016/j.ejbt.2019.03.007.

Bowland, E. L., and E. A. Foegeding. 1999. Factors determining largestrain (fracture) rheological properties of model processed cheese. J. Dairy Sci. 82:1851-1859. https://doi.org/10.3168/jds.S0022 -0302(99)75418-4.

Brun, L. R., M. Lupo, D. A. Delorenzi, V. E. Di Loreto, and A. Rigalli. 2013. Chicken eggshell as suitable calcium source at home. Int J. Food Sci. Nutr. 64:740-743. https://doi.org/10.3109/09637486 .2013.787399.

Camardo Leggieri, M., S. Decontardi, and P. Battilani. 2018. Modelling the sporulation of some fungi associated with cheese, at different temperature and water activity regimes. Int. J. Food Microbiol. 278:52-60. https://doi.org/10.1016/j.ijfoodmicro.2018.04.023.

Chudy, S., and A. Makowska. 2014. Tvarog (acid curd cheese) and ripened fried cheese - Yesterday and today. Zeszyty Wiejskie [Rural Periodicals] XX:167-175.

da Silva, B. P., R. C. L. Toledo, M. Grancieri, M. E. C. Moreira, N. R. Medina, R. R. Silva, N. M. B. Costa, and H. S. D. Martino. 2019a. Effects of chia (Salvia hispanica L.) on calcium bioavailability and inflammation in Wistar rats. Food Res. Int. 116:592-599. https:// doi.org/10.1016/j.foodres.2018.08.078.

da Silva, D. D., M. S. Falcão de Lima, M. F. da Silva, G. R. da Silva, J. F. Campos, W. W. Albuquerque, M. T. H. Cavalcanti, and A. L. F. Porto. 2019b. Bioactive water-soluble peptides from fresh buffalo cheese may be used as product markers. LWT 108:97-105. https://doi.org/10.1016/j.lwt.2019.03.035.

De Marchi, M., C. C. Fagan, C. P. O'Donnell, A. Cecchinato, R. Dal Zotto, M. Cassandro, M. Penasa, and G. Bittante. 2009. Prediction of coagulation properties, titratable acidity, and $\mathrm{pH}$ of bovine milk using mid-infrared spectroscopy. J. Dairy Sci. 92:423-432. https://doi.org/10.3168/jds.2008-1163.

Gluvić, A., and N. P. Ulrih. 2019. Peptides derived from food sources: Antioxidative activities and interactions with model lipid membranes. Food Chem. 287:324-332. https://doi.org/10.1016/j .foodchem.2019.02.092.

Gramza-Michałowska, A., J. Kobus-Cisowska, D. Kmiecik, J. Korczak, B. Helak, K. Dziedzic, and D. Górecka. 2016. Antioxidative potential, nutritional value and sensory profiles of confectionery fortified with green and yellow tea leaves (Camellia sinensis). Food Chem. 211:448-454. https://doi.org/10.1016/j.foodchem.2016.05.048.

ISO. 2017. ISO 18787:2017: Foodstuffs - Determination of water activity. https://www.iso.org/standard/63379.html.

Jarzębski, M., B. Bellich, T. Białopiotrowicz, T. Śliwa, J. Kościński, and A. Cesàro. 2017. Particle tracking analysis in food and hydrocolloids investigations. Food Hydrocoll. 68:90-101. https://doi .org/10.1016/j.foodhyd.2016.09.037.

Lentas, K., and D. Witrowa-Rajchert. 2008. Effect of initial infusion with calcium ions on some selected properties of dried apples. Żywn. Nauk. Techn. Jakość. 5:178-188.

Ley, J. P. 2008. Masking bitter taste by molecules. Chem. Percept. 1:58-77. https://doi.org/10.1007/s12078-008-9008-2.

Li, X., M. Ma, D. U. Ahn, and X. Huang. 2019. Preparation and characterization of novel eggshell membrane-chitosan blend films for potential wound-care dressing: From waste to medicinal products. Int. J. Biol. Macromol. 123:477-484. https://doi.org/10.1016/j ijbiomac.2018.10.215.

Lynch Cronin, I., F. Byrne, R. Doyle, W. D. Fraser, A. Chipchase, and J. A. Eustace. 2019. The effect of short-term vitamin D supplementation on calcium status in vitamin D insufficient renal transplant recipients at risk of hypercalcemia. J. Ren. Nutr. 29:181-187. https://doi.org/10.1053/j.jrn.2018.11.012.

Majcher, M. A., K. Myszka, J. Kubiak, and H. H. Jelen'. 2014. Identification of key odorants of fried cottage cheese and contribution of Galactomyces geotrichum MK017 to the formation of 2-phenylethanol and related rose-like aroma compounds. Int. Dairy J. 39:324-329. https://doi.org/10.1016/j.idairyj.2014.08.008.

Morandi, S., T. Silvetti, G. Battelli, and M. Brasca. 2019. Can lactic acid bacteria be an efficient tool for controlling Listeria monocytogenes contamination on cheese surface? The case of Gorgon- 
zola cheese. Food Control 96:499-507. https://doi.org/10.1016/j .foodcont.2018.10.012.

Polish Standardizing Committee. 2014. PN-EN 13805:2014-11: Foodstuffs-Determination of trace elements: Pressure digestion. Polish Standardizing Committee, Warsaw, Poland.

Quina, M. J., M. A. R. Soares, and R. Quinta-Ferreira. 2017. Applications of industrial eggshell as a valuable anthropogenic resource. Resour. Conserv. Recycling 123:176-186. https://doi.org/10.1016/ j.resconrec.2016.09.027.

Ray, S., A. K. Barman, P. K. Roy, and B. K. Singh. 2017. Chicken eggshell powder as dietary calcium source in chocolate cakes. Pharma Innov. J. 6:01-04.

Ren, Q. C., J. J. Xuan, L. K. Wang, Z. Z. Hu, H. J. Yang, W. Zhang, and L. S. Jiang. 2018. Effects of tributyrin supplementation on in vitro culture fermentation and methanogenesis and in vivo dietary nitrogen, calcium and phosphorus losses in Small Tail ewes. Anim. Feed Sci. Technol. 243:64-71. https://doi.org/10.1016/j.anifeedsci 2018.07.008

Rezler, R., and S. Poliszko. 2010. Temperature dependence of starch gel rheological properties. Food Hydrocoll. 24:570-577. https://doi .org/10.1016/j.foodhyd.2010.02.003.
Schiffman, S. S., and C. Dackis. 1975. Taste of nutrients: Amino acids, vitamins, and fatty acids. Percept. Psychophys. 17:140-146. https: //doi.org/10.3758/BF03203878.

Szpendowski, J., J. Kłobukowski, K. Bohdziewicz, and M. Kujawski. 2004. Characteristics of the chemical composition of the nutritive value of protein in selected curd cheeses. Pol. J. Nat. Sci. 2(Suppl.):143-150.

Szpendowski, J., J. Kłobukowski, and E. Prokop. 2005. The effect of calcium chloride added to milk and milk heating on the chemical composition of cottage cheeses. Żywn. Nauk. Techn. Jakość. $3: 36-45$.

Wu, W., L. He, Y. Liang, L. Yue, W. Peng, G. Jin, and M. Ma. 2019. Preparation process optimization of pig bone collagen peptide-calcium chelate using response surface methodology and its structural characterization and stability analysis. Food Chem. 284:80-89 https://doi.org/10.1016/j.foodchem.2019.01.103.

Zanutto-Elgui, M. R., J. C. S. Vieira, D. Z. do Prado, M. A. R. Buzalaf, and L. F. Fleuri. 2019. Production of milk peptides with antimicrobial and antioxidant properties through fungal proteases. Food Chem. 278:823-831. https://doi.org/10.1016/j.foodchem .2018.11.119. 